\title{
Pendampingan Belajar Dasar Berhitung bagi Siswa SD di Mata Jemaat Ebenhaezer Mabu Alor
}

\author{
Landerius Maro*, Lekison Padafani ${ }^{2}$ \\ 1,2 Universitas Tribuana Kalabahi, Alor, Indonesia \\ *Corresponding Author: landeriusmaro@gmail.com
}

Info Artikel

Diterima: 26/01/2022

Direvisi: $12 / 02 / 2022$

Disetujui: $14 / 02 / 2022$

\begin{abstract}
The outbreak of COVID 19 has resulted in educational institutions implementing an online learning system and the impact on students' declining abilities in mathematics. This service activity aims to help students understand the material about the basics of counting outside of school hours. This service activity was carried out at the Ebenhaezer Mabu Congregation, Alor Regency with the target of junior high school students in the area. This activity was carried out for 6 meetings, starting with the pretest and ending with the posttest. This activity is said to be successful because of the positive response from students and parents to this activity and an increase in scores between the pretest and posttest.
\end{abstract}

Keywords: Learning assistance, Basics of Counting.

\begin{abstract}
Abstrak. Kondisi mewabahnya COVID 19 mengakibatkan lembaga pendidikan menerapkan sistem pembelajaran daring dan berdampak pada kemampuan siswa/i yang menurun dalam pelajaran matematika. Kegiatan pengabdian ini bertujuan membantu siswa/i untuk memahami materi tentang dasar - dasar berhitung di luar jam sekolah. Kegiatan pengabdian ini dilaksanakan di Mata Jemaat Ebenhaezer Mabu, Kabupaten Alor dengan sasaran siswa/i SMP di wilayah tersebut. Kegiatan ini dilakukan selama 6 kali pertemuan yang diawali dengan pretest dan diakhiri dengan posttest. Kegiatan ini dikatakan berhasil karena adanya respon positif dari siswa/i dan orang tua terhadap kegiatan ini dan adanya peningkatan nilai antara pretest dan posttest.
\end{abstract}

Kata Kunci: Pendampingan pembelajaran, Dasar-dasar berhitung.

How to Cite: Maro, R., \& Padafani, L. (2022). Pendampingan Belajar Dasar Berhitung bagi Siswa SD di Mata Jemaat Ebenhaezer Mabu Alor. Prima Abdika: Jurnal Pengabdian Masyarakat, 2(1), 62-68. https://doi.org/10.37478/abdika.v2i1.1643

\section{Pendahuluan}

Pemerintah Indonesia sebagaimana tertuang dalam Pembukaan Undang - Undang Dasar Tahun 1945 berperan dalam upaya mencerdaskan kehidupan bangsa. Peran tersebut dilakukan melalui kegiatan pendidikan, baik itu pendidikan formal, nonformal,dan infornal. Pendidikan merupakan wadah yang memberikan suatu pengajaran kepada peserta didik dari yang tidak tahu menjadi tahu dengan tujuan untuk meningkatkan bakat minat peserta didik (Jera, 2020). Keadaan pendidikan di wilayah Indonesia saat ini tengah berkembang menjadi lebih baik, meskipun masih tertinggal disbanding negara berkembang lainnya. Pendidikan yang diterapkan di Indonesia, secara sistem belum bias dikatakan berhasil dengan baik. Indikatornya adalah lulusan yang dihasilkan masih kurang berkualitas (Hidayatullah, 2016). Rendahnya kualitas lulusan bukan hanya dipengaruhi dari dalam diri individu, melainkan bersumber juga dari luardiri individu tersebut. Menurut Noor Komari (2015), Pendidikan merupakan proses sistematis yang melibatkan faktor internal maupun eksternal. Faktor internal dating dari diri siswa seperti minat belajar, motivasi belajar, bakat dan persepsi, baik persepsi siswa terhadapat mata pelajaran maupun terhadap guru pengajar. Sedangkan faktor eksternal datang dari luar diri siswa, seperti 
lingkungan belajar, lingkungan keluarga, latar belakang social ekonomi keluarga dan perhatian orang tua dalam membantu mengatasi kesulitan belajar yang dialami anak (Pahmi et al., 2021).

Dalam sistem pendidikan, khususnya pendidikan formal baik itu pendidikan dasar, pendidikan menengah, maupun pendidikan tinggi tidak pernah terlepas dari pembelajaran tentang ilmu matematika. Matematika ditransformasikan dalam pendidikan pada setiap jenjang. Kendati sejak dini sudah mulai diajarkan, patut diakui bahwa matematika masih terasa sulit bagi sebagian orang. Selain itu, sebagian dari mereka tidak memilih untuk bersekolah hanya karena menghindari mata pelajaran matematika (Hidayatullah, 2018). Kendati demikian, ilmu matematika tetap harus dipelajari karena kegunaannya yang dapat diterapkan ke segala bidang kehidupan.

Kegiatan pembelajaran di berbagai belahan dunia, terkhusus di Indonesia dalam dua tahun terakhir sangat memprihatikan. Hal ini dikarenakan menyebarnya virus COVID 19 di seluruh dunia yang memaksa setiap lembaga pendidikan di Indonesia untuk merumahkan seluruh aktifitas pembelajaran melalui kegiatan pembelajaran daring. Penelitian Lin et al. (2017) menyatakan bahwa kemampuan dan hasil belajar siswa dapat meningkat melalui pembelajaran daring. Walaupun demikian, pemanfaatan $e-$ lerning (daring) tidak semuanya berjalan dengan baik. Hal ini memunculkan berbagai keluhan dan kekhwatiran dari masyarakat, khususnya orang tua siswa yang berasal dari masyarakat kelas menengah ke bawah, karena mendapat kendala dalam mengikuti proses kegiatan belajar daring tersebut dan sebagian dari mereka tidak memiliki handphone atau teknologi yang dapat digunakan dalam menunjang kegiatan belajar daring tersebut (Leasa, 2021). Selain itu, dampak lain yang dirasakan siswa saat belajar di rumah secara daring adalah para siswa merasa dipaksa untuk belajar jarak jauh atau online tanpa sarana dan prasarana yang memadai di rumah. Fasilitas sangat penting untuk kelancaran proses belajar mengajar secara daring yang akan memudahkan siswa untuk menyimak pelajaran. Kendala selanjutnya yaitu para siswa belum mempunyai pengalaman untuk belajar jarak jauh karena selama ini pembelajaran dilaksanakan secara luring atau melalui tatap muka, siswa terbiasa berada di sekolah untuk berinteraksi dengan teman - temannya, bermain dan bercanda gurau dengan teman - temannya serta bertatap muka dengan para gurunya, dengan adanya metode pembelajaran daring (online) membuat para siswa perlu waktu untuk beradaptasi dan mereka menghadapi perubahan baru yang secara tidak langsung akan mempengaruhi daya serap belajar mereka (Qashasy et al., 2020)

Kondisi ini juga dialami oleh setiap siswa dalam memahami materi mata pelajaran matematika, apalagi dalam proses pembelajaran daring. Dengan demikian kemampuan siswa akan terlambat dalam mempelajari materi mata pelajaran matematika dan kemampuan dasar menghitung bagi mereka akan semakin rendah pada saat ini dalam memulai proses pembelajaran tatap muka (luring) di sekolah. Hal yang sama dialami oleh siswa/i Sekolah Dasar (SD) di Kabupaten Alor, Propinsi Nusa Tenggara Timur, sehingga perlu adanya pendampingan berupa penguatan - penguatan dasar berhitung bagi siswa/i tersebut selain yang diperoleh di sekolah. Pendampingan tersebut dapat berupa pendidikan non formal baik itu 
penambahan waktu belajar di luar jam pelajaran, mengikuti kelas - kelas khusus yang diselenggarakan lembaga pendidikan non formal, bahkan pendampingan yang dilakukan oleh tim - tim relawan melalui pihak desa, sekolah, maupun tempat ibadah.

Universitas Tribuana (Untrib) Kalabahi merupakan perguruan tinggi yang berada di wilayah Kabupaten Alor dan memiliki 11 program studi yang salah satunya adalah Program Studi Matematika. Program Studi Matematika dalam menjalankan salah satu misinya, yaitu melaksanakan pengabdian pada masyarakat melalui penyebarluasan dan penerapan ilmu matematika sehingga meningkatkan apresiasi masyarakat terhadap ilmu matematika dalam rangka lebih membumikan matematika kepada masyarakat, merasa terpanggil untuk menjawab permasalahan yang dialami oleh siswa/i tersebut. Kegiatan pengabdian kepada masyarakat merupakan salah satu dari tiga komponen kegiatan yang berada dalam pergumulan suatu lembaga pendidikan tinggi atau merupakan bagian tri dharma perguruan tinggi selain kegiatan pendidikan dan penelitian. Dengan terlaksananya kegiatan pengabdian tersebut di samping kedua kegiatan lainnya, diharapkan dapat terjalin hubungan timbal balik antaraperguruan tinggi dan masyarakat yang terkena dampak dari kegiatan pengabdian atau sekitarnya (Muttaqin \& Faishol, 2018). Atas dasar itu, Program Studi Matematika Untrib telah melaksanakan beberapa kegiatan pengabdian yang bertujuan memberi penguatan tentang dasar - dasar berhitung bagi siswa/i SD di berbagai wilayah di Kabupaten Alor pada luar jam pelajaran baik itu melalui pihak sekolah, desa, maupun pihak gereja.

Salah satu kegiatan pengabdian yang telah dilaksanakan adalah kegiatan pengabdian dengan judul "Pendampingan Belajar Dasar Berhitung Bagi Siswa/i SD di Mata Jemaat Ebenhaezer Mabu, Alor".

\section{Metode Pelaksanaan}

Kegiatan ini dilaksanakan melalui pihak Gereja dengan sasaran Kelompok Anak Sekolah Minggu atau Pekan Anak dan Remaja (PAR) usia SD kelas V dan VI di wilayah Mata Jemaat Ebenhaezer Mabu yang berlokasi di Kecamatan Alor Tengah Utara (ATU), Kabupaten Alor, Provinsi Nusa Tenggara Timur. Kegiatan ini dilaksanakan selama bulan November 2021 yang mana penjadwalannya pada setiap hari Selasa dan Jumat selama 6 kali pertemuan. Kegiatan ini merupakan kegiatan pembelajaran tatap muka dengan metode ceramah, diskusi, dan tanya jawab yang dibagi menjadi tiga tahapan. Adapun tahap - tahap dalam kegiatan pendampingan ini, yaitu :

1. Tahap Pendahuluan (Pertemuan 1)

Tahap pendahuluan yang dilakukan yaitu melaksanakan pretest tentang soal materi dasar matematika seperti operasi penjumlahan, pengurangan, perkalian, dan pembagian pada bilangan bulat dan pecahan. Hal ini bertujuan untuk mengetahui tingkat pengetahuan siswa/i mengenai dasar - dasar berhitung.

2. Tahap Pelaksanaan (Pertemuan $2 \mathrm{~s} / \mathrm{d}$ 5)

Tahap pelaksanaan pendampingan dilakukan sebanyak 4 kali pertemuan dengan durasi waktu 120 sampai dengan 150 menit setiap pertemuan. Sebelum kegiatan ini berlangsung, siswa/i diberikan 
gambaran mengenai tujuan dan pentingnya materi yang akan dipelajari. Materi yang diajarkan yaitu operasi penjumlahan, pengurangan, perkalian, pembagian, dan perpangkatan pada bilangan bulat dan pecahan. Setiap kegiatan dalam tahap pelaksanaan ini menggunakan metode ceramah, diskusi dan tanya jawab.

3. Tahap Evaluasi (Pertemuan 6)

Setelah pemberian materi pendampingan, dilakukan evaluasi yang diberikan dalam bentuk posttest sesuai materi yang diberikan. Hal ini bertujuan untuk melihat tingkat pemahaman anak terhadap materi yang diberikan dan sekaligus untuk mengukur tingkat keberhasilan kegiatan pendampingan.

\section{Hasil dan Pembahasan}

Kegiatan pendampingan ini dilakukan dengan 3 tahap kegiatan, yaitu pendahuluan, pelaksanaan, dan evaluasi. Adapun uraian dan hasil kegiatan sebagai berikut :

1. Tahap pendahuluan (Pertemuan 1)

Tahap ini merupakan kegiatan awal, yang mana digunakan untuk perkenalan antara pendamping dan peserta, penyampaian tujuan dan tahap kegiatan, serta pelaksanaan tes awal (pretest) dengan tujuan untuk mengetahui kemampuan awal peserta dalam menguasai dasar - dasar berhitung pada bilangan bulat dan pecahan. Adapun hasil analisis pretest dari ke -32 orang peserta dapat dilihat pada gambar 1 berikut.

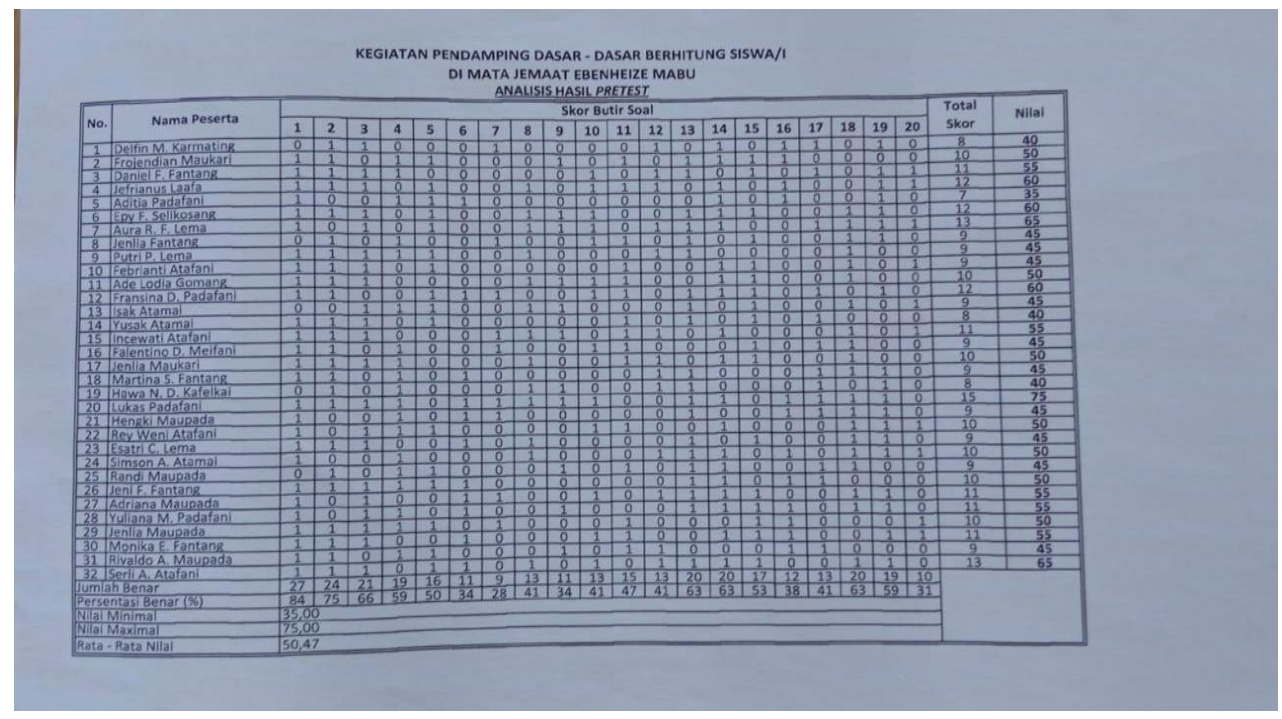

Gambar 1. Dokumentasi Hasil Analisis Pretest

Berdasarkan gambar 1 di atas, dapat disimpulkan bahwa kemampuan awal peserta masil sangat rendah. Hal ini terlihat dari rata rata nilai pretest adalah 50,47, nilai terendah adalah 35,00 , dan nilai tertinggi hanya 75,00 . Sedangkan butir soal yang dianggap paling sulit adalah soal nomor 6 dengan hanya 9 peserta menjawab benar.

2. Tahap pelaksanaan (Pertemuan $2 \mathrm{~s} / \mathrm{d} 5$ )

Tahap ini merupakan kegiatan belajar mengajar (KBM) dengan menggunakan metode ceramah, diskusi, dan tanya jawab. Materi KBM ini 
di antaranya penjumlahan, pengurangan, perkalian, pembagian, dan perpangkatan pada bilangan bulat (positif maupun negatif) dan bilangan pecahan (pecahan biasa). Penekanan dalam pemberian materi didasarkan pada hasil analisis pretest dengan mempertimbangkan tingkat kesulitan dari setiap butir soal. Berdasarkan hasil pantauan pendamping dalam KBM dan daftar hadir, terlihat bahwa keaktifan peserta sangat tinggi dan bersemangat mengikuti KBM tersebut. Berikut adalah dokumentasi kegiatan dan daftar hadir peserta selama kegiatan pendampingan berlangsung yang dapat dilihat pada gambar 2 berikut.

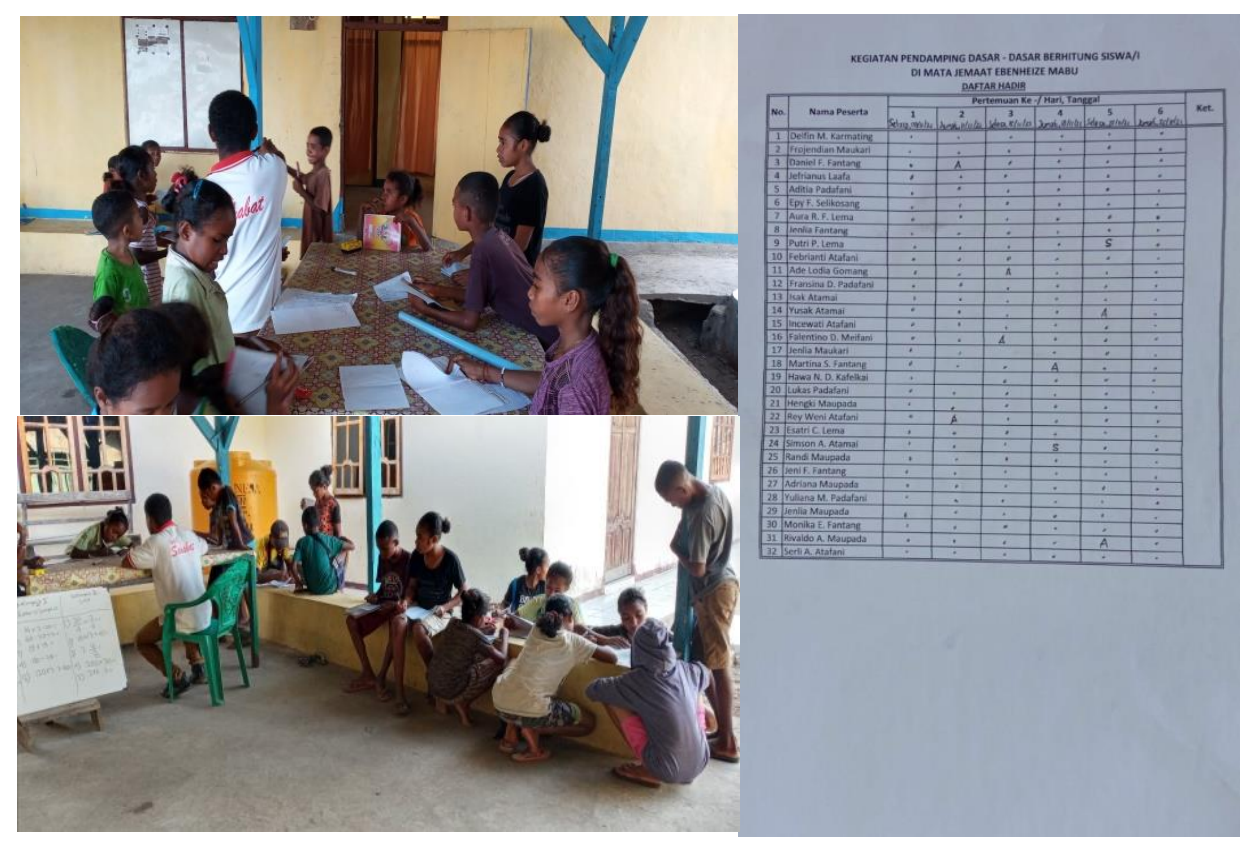

Gambar 2. Dokumentasi Pelaksanaan Kegiatan dan Daftar Hadir

3. Tahap evaluasi (Pertemuan 6)

Tahap ini merupakan kegiatan akhir, yang mana digunakan untuk pelaksanaan tes akhir (posttest) dengan tujuan untuk mengetahui tingkat keberhasilan kegiatan pendampingan ini. Adapun hasil analisis posttest dari ke - 32 orang peserta dapat dilihat pada gambar 3 berikut.

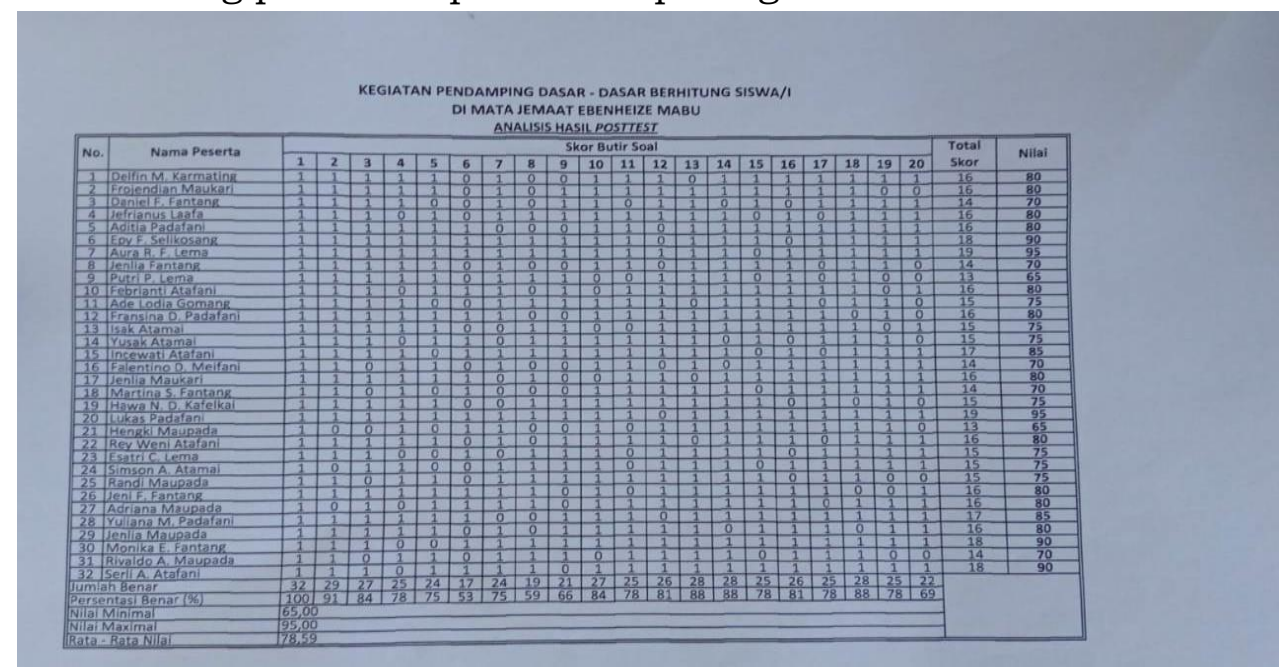

Gambar 3. Dokumentasi Hasil Analisis Posttest 
Berdasarkan gambar 3 di atas, dapat disimpulkan bahwa kegiatan pendampingan berhasil meningkatkan kemampuan dasar - dasar berhitung pada bilangan bulat dan pecahan. Hal ini terlihat dari rata rata nilai posttest adalah 78,59 atau meningkat $55,72 \%$ dari rata - rata nilai pretest, nilai terendah adalah 65,00 atau meningkat $85,71 \%$ dari nilai terendah pretest, dan nilai tertinggi adalah 95,00 atau meningkat $22,22 \%$ dari nilai tertinggi pretest. Sedangkan tingkat kesulitan setiap butir soal rata - rata mengalami penurunan dilihat dari jumlah jawaban benar peserta untuk setiap butir soal rata - rata mengalami peningkatan.

Dalam pelaksanaan kegiatan pendampingan ini terdapat beberapa kekurangan, di antaranya belum tersedianya ruang belajar dengan kapasistas dan fasilitas yang memadai dikarenakan jumlah peserta yang mengikuti kegiatan ini cukup banyak, yaitu berjumlah 32 orang. Kendati terdapat kekurangan - kekurangan tersebut, peserta maupun pemateri sangat antusias dalam memberi dan menerima materi pada kegiatan pendampingan ini. Selain itu, respon orang tua juga sangat positif terhadap kegiatan ini.

Kegiatan ini dapat dikatakan berhasil dengan merujuk pada indikator pencapaian pembelajaran, yaitu adanya peningkatkan nilai yang signifikan antara hasil pretest dan posttest.

\section{Simpulan dan Tindak Lanjut}

Kegiatan pendampingan pembelajaran ini dirasakan sangat bermanfaat bagi peserta karena dapat meningkatkan kemampuan dasar berhitung bagi peserta yang dilihat dari perbandingan nilai pretest dan posttest dari setiap peserta. Namun di dalam pelaksanaannya masih terdapat keterbatasan yaitu kapasitas dan fasilitas ruang belajar yang belum memadai. Selain itu, berdasarkan hasil diskusi bersama orang tua diperoleh saran/masukan terkait perlunya kegiatan pendampingan dilakukan secara rutin, pendampingan yang diberikan bukan hanya materi tentang operasi hitung bilangan bulat dan pecahan, dan perbanyak permainan matematika untuk mengurangi kebosanan di dalam pembelajaran.

\section{Daftar Pustaka}

Hidayatullah, A. (2016). Pendampingan Pendidikan Anak di Kelurahan Genteng Surabaya. Aksiologiya: Jurnal Pengabdian Kepada Masyarakat, 1(1), 45. https://doi.org/10.30651/aks.v1i1.296

Hidayatullah, A. (2018). Pendampingan Relawan Matematika Asyik (Rematika) Terhadap Siswa di Sekolah dan Anak-Anak Nelayan Pinggir Pantai Kenjeran Surabaya. AKSIOLOGIYA: Jurnal Pengabdian Kepada Masyarakat, 2(1), 39-49. https://doi.org/10.30651/aks.v2i1.1240

Jera, R. P. (2020). Pendampingan Les Tambahan Mata Pelajaran Matematika di Taman Baca Gracia melalui Bimbingan Belajar Peserta Didik di Kelurahan Prailiu. Jurnal Pengabdian Barelang, 2(03), 1-4. https://doi.org/ 10.33884/jpb.v2i03.1969

Leasa, R. E. (2021). BIMBINGAN BELAJAR MATEMATIKA BAGI ANAK DI DUSUN MAHIA Rola Evalin Leasa *. 1, 56-63.

Muttaqin, A. I., \& Faishol, R. (2018). Pendampingan Pendidikan Non Formal Diposdaya Masjid Jami'an-Nur Desa Cluring Banyuwangi. ABDI KAMI: Jurnal Pengabdian Kepada Masyarakat, 1(1), 80-90. 
http://ejournal.iaiibrahimy.ac.id/index.php/Abdi_Kami/article/view/235

Pahmi, S., Suciani, A., Yulianti, R., Putri, C. S., \& Sagita, T. (2021). Pendampingan Belajar Di Masa Pandemi Covid-19 Untuk Meningkatkan Motivasi dan Minat Belajar Siswa Di Desa Gegerbitung. Jurnal Komunitas: Jurnal Pengabdian Kepada Masyarakat, 4(1), 55-59. http://ojs.stiami.ac.id

Qashasy, A., Syamsiyah, L., Rofi'ah, N. A. A., Kolbi, M. K., Janan, S., \& Supriyanto, T. (2020). PENDAMPINGAN BELAJAR DARI RUMAH PADA ANAK-ANAK SELAMA MASA PANDEMI COVID-19 DALAM RANGKA MENINGKATKAN KEMAMPUAN ANAK DAN MEMBANTU ORANGTUA DI KABUPATEN PEKALONGAN. 25(3), 1-23. 